Kumawula, Vol. 3, No.2, Agustus 2020, Hal 325 - 335 DOI: https://doi.org/10.24198/kumawula.v3i2.27168

ISSN 2620-844X (online)

Tersedia online di http://jurnal.unpad.ac.id/kumawula/index

\title{
PEMANFAATAN PEKARANGAN UNTUK KEWIRAUSAHAAN KELUARGA DI DESA CIPACING BERBASIS PENANAMAN BIBIT JERUK LEMON
}

\author{
Wahju Gunawan \\ Sekolah Pascasarjana, Fakultas Ilmu Sosial Ilmu Politik, Universitas Padjadjaran \\ wahyu.gunawan@unpad.ac.id
}

\begin{abstract}
ABSTRAK
Desa Cipacing merupakan kawasan dengan lahan pertanian yang produktif akan tetapi seiring terjadinya perubahan orientasi kawasan di Kecamatan Jatinangor dari yang tadinya kawasan pertanian menjadi kawasan pendidikan, Desa Cipacing pun turut berubah menuju kawasan industri. Pengabdian ini dilakukan untuk memberikan alternatif kegiatan kewirausahaan dengan manfaat kepada kebersihan, keindahan dan kenyamanan lingkungan warga khususnya lingkungan rumah dengan pemukiman padat juga memberikan keuntungan dari hasil menanam bibit jeruk lemon di pekarangan untuk peningkatan pendapatan sekaligus kegiatan kewirausahaan keluarga. Metode penelitian yang digunakan untuk pengambilan sampel adalah dengan menggunakan purposive sampling, disertai survey dan wawancara sedangkan untuk membuat analisa menggunakan analisis kualitatif dan peran warga aktif. Hasil dan temuan dari pengabdian ini adalah dapat diketahui bahwa masyarakat Desa Cipacing khususnya di RW 01, 07, 15 dan 18 sudah menyadari bahwa dengan adanya program penanaman tanaman jeruk lemon, masyarakat memahami bahwa penghijauan lingkungan sekitar sangatlah diperlukan mengingat wilayah Desa Cipacing merupakan pemukiman padat penduduk. Akan tetapi disisi lain masyarakat belum memahami secara jangka panjang bahwa bibit jeruk lemon tersebut bisa menghasilkan profit keberlanjutan untuk setiap keluarga. Dengan demikian, diperlukannya pengembangan sebuah lembaga sosial seperti GAPOKTAN (Gabungan Kelompok Tani) yang dapat mengembangkan potensi warga dengan usaha bibit jeruk lemon dari mulai proses cara menanam, merawat, hingga sampai menjual produk untuk memenuhi permintaan pasar.
\end{abstract}

Kata kunci: Kewirausahaan Keluarga, Penghijauan Lingkungan, Warga Aktif, GAPOKTAN.

\section{UTILIZING THE COURTYARD FOR FAMILY ENTREPRENEURSHIP BASED ON CULTIVATING LEMONADE SEEDS IN CIPACING VILLAGE}

\begin{abstract}
Cipacing village is a farmland area which is highly productive but is facing the issue of area reorientation of Jatinangor sub-district from farmland to educational area, which would also transform Cipacing village into industry area. This community service program proposes to give alternative solution relating to entrepreneurship with cleanliness, beauty and safety for the home environment especially in densely populated areas, and to create profit from planting lemonade seeds in the courtyard to increase income and entrepreneurship activities of families. The method that is used to take samples is purposive sampling with survey and interview while data analysis uses qualitative analysis and people's involvement. The result and findings from this program found that with cultivating lemonade, the people comprehend that area greening is a must since Cipacing
\end{abstract}


village is densely populated. Although, the people still have not accepted that future lemonade seeds planting can yield sustainable profit for families. Therefore, it takes social institutions such as GAPOKTAN (the farmer group) that could develop the people's potency by planting lemonade seeds from the beginning process of how to plant, maintain until selling the product to fulfilling the market demand.

Keywords: Family Entrepreneurship, Greening the Environment, Active Citizens, GAPOKTAN.

\section{PENDAHULUAN}

Cipacing sebagai sebuah desa penghasil kerajinan berupa senapan angin dengan bentuk yang beraneka ragam dan memiliki produk kerajinan lainnya seperti patung, alat musik dan berbagai bentuk jenis kerajinan lainnya. Warga-warga yang berada di Desa Cipacing memiliki kreatifitas yang luar biasa dalam mengolah berbagai kerajinan tangan yang dihasilkan. Kemampuan mengolah berbagai kerajinan ini merupakan keahlian turun temurun. Begitu banyak warga yang mengupayakan kerajinan tersebut membuktikan bahwa warga desa ini telah menjalankan kewirausahaannya secara mandiri.

Potensi lain dari Desa Cipacing yaitu kondisi alam yang masih asri, rimbunnya pepohonan, hijau dan luasnya lahan pertanian masih menjadi pemandangan yang khas di desa ini. Akan tetapi seiring berjalannya pembangunan infrastruktur yang pesat serta menjamurnya usahausaha produk dan jasa, wilayah di beberapa Desa Cipacing menjadi sempit sehingga wilayah pekarangan rumah menjadi hal yang tidak diperhatikan. Kondisi pekarangan yang tidak terurus, menambah ketidakindahan dan ketidaknyamanan lingkungan, sehingga jauh dari kebersihan yang menjadi pangkal kumuhnya sebuah wilayah. Padahal bila lahan pekarangan ini dimanfaatkan oleh masyarakat, akan memberikan dampak signifikan terhadap penambahan pendapatan rumah tangga serta kelestarian lingkungan sekitar rumah. Merawat dan mengelola pekarangan adalah sebuah kegiatan yang selain mempercantik lingkungan rumah juga bisa menghasilkan keuntungan untuk anggota keluarga.

Pekarangan adalah lahan terbuka yang terdapat di sekitar rumah tinggal (Kurnianingsih et al., 2013). Pekarangan rumah merupakan salah satu lahan potensial yang sering dilupakan penggunaannya. Pemanfaatan pekarangan rumah dengan menanamnya dengan tanaman yang berjual nilai tinggi dapat meningkatkan pendapatan keluarga sebuah keluarga (Latief, Tafzi dan Aryunis, 2013). Pemanfaatan pekarangan untuk pengembangan usaha tani belum banyak dilakukan oleh masyarakat. Hal ini dikarenakan lahan pekarangan yang relatif sempit, sehingga pada umumnya difungsikan untuk mendirikan bangunan rumah dan juga mengelola taman.

Untuk itu, dalam kegiatan Program Pengabdian Masyarakat (PPM) kali ini bersama 
mahasiswa KKN-Kewirausahaan berusaha untuk memanfaatkan lahan pekarangan rumah warga di sekitar sebagai dengan menanam bibit pohon jeruk lemon.

Jeruk lemon merupakan komoditas yang digunakan dalam berbagai masakan. Air perasannya digunakan sebagai bahan makanan baik untuk konsumsi komersial maupun rumahan, dan bernilai karena rasanya yang asam, tajam, dan segar. Kulit buah lemon yang harum bisa dimanfaatkan sebagai hiasan dan penyedap serta merupakan sumber utama minyak esensial dan aroma senyawa komersial. Bunga lemon beraroma manis, dengan aroma yang mirip dengan bunga jeruk lainnya. Minyak esensial dari bunga, ranting, dan buah dapat disuling atau diekstrak untuk mendapatkan bahan yang cocok digunakan dalam rasa dan wewangian. (Goodrich, 2003).

Selain dalam dunia kuliner, lemon memiliki segudang manfaat lainnya dalam berbagai bidang. Lemon juga biasanya digunakan pada pewangi, deterjen, obat, kosmetik, dan aroma terapi. (Ammad, F., Moumen, O., Gasem, A., Othmane, S., Hisashi, K.-N., Zebib, B., Merah, O, 2018). Selain manfaatnya bisa di konsumsi untuk kebutuhan sehari-hari oleh setiap anggota keluarga, peluang dalam berwirausaha jeruk lemon cukup prospektif dikarenakan permintaan pasar pada jeruk lemon juga tinggi seperti yang dikemukakan oleh Nugraha (2019) bahwa prospek jeruk lemon saat ini cukup cerah dan peluang pasarnya luas. Selama ini permintaannya cukup banyak, namun produksi jeruk lemon dari petani belum mampu memenuhi tingginya permintaan tersebut. Pendorong tingginya permintaan karena pertumbuhan kuliner dan perkembangan resto dan hotel di kota-kota besar di Tanah Air cukup pesat, sehingga berdampak signifikan terhadap permintaan jeruk lemon.

Potensi sumber daya alam yang cukup besar di Desa Cipacing seharusnya masih bisa ditingkatkan pemanfaatannya secara maksimal khususnya untuk pengembangan tanaman jeruk lemon di pekarangan rumah tinggal. Apabila potensi pekarangan yang cukup besar ini dikelola dengan baik dan optimal maka akan memberikan konstribusi yang positif terhadap penyediaan pangan, perbaikan gizi, mengurangi pengeluaran keluarga dan atau menambah pendapatan keluarga (Ruswadi, Rustiyadi dan Mudikdjo, 2007).

Hal ini yang menjadikan komoditas jeruk lemon disamping bermanfaat sebagai konsumsi sehari-hari, juga mampu menjadi sebuah keuntungan dalam jangka panjang dengan menanam bibit buah jeruk lemon. Selain sebagai konsumsi sehari-hari bagi anggota keluarga dengan wilayah pemukiman yang cenderung relatif padat, warga Desa Cipacing tetap membutuhkan asupan oksigen yang segar, sehat dan sejuk selain profitnya dari hasil buah yang akan ditanam. 
Sehingga bukan karena pemukiman padat sebagai alasan untuk tidak memanfaatkan lahan pekarangan dalam menanam akan tetapi karena kurang kesadaran betapa lingkungan yg menghasilkan oksigen sangat membantu kesehatan lingkungan untuk itu diperlukan sebuah gerakan merubah kesadaran akan pentingnya lingkungan.

Adapun tujuan dari kegiatan pengabdian kepada masyarakat ini adalah memberikan alternatif kegiatan kewirausahaan dengan manfaat kepada kebersihan, keindahan dan kenyamanan lingkungan warga khususnya lingkungan rumah juga memberikan keuntungan dari hasil menanam di pekarangan untuk peningkatan pendapatan sekaligus kegiatan kewirausahaan keluarga. Usahatani di pekarangan jika dikelola secara intensif sesuai dengan potensi pekarangan, disamping dapat memenuhi kebutuhan konsumsi rumah tangga, juga dapat memberikan sumbangan pendapatan bagi keluarga (Yulida, 2012).

Selanjutnya adalah memberikan proses pemahaman kepada mahasiswa peserta KKN untuk mencari alternatif lain kegiatan kewirausaahan keluarga di lahan yang terbatas, tetapi efesien secara pengelolaan dan efektif dalam mencapai tujuan benefit yaitu sebagai konsumsi seharihari anggota keluarga serta profit secara finansial sekaligus meningkatkan kebersihan lingkungan dengan harapan bisa menumbuhkan oksigen yang sehat di tengah padatnya pemukiman penduduk saat ini. Pada prinsipnya KKN adalah terjadinya interaksi sosial yang berdampak pada tumbuhnya empati mahasiswa terhadap masalah masyarakat yang dapat menghasilkan solusi baik berjangka pendek saat kegiatan KKN berlangsung ataupun kedepannya sehingga menjadi sebuah tantangan dalam KKN Kewirausahaan adalah solusi yg diusulkan, benar efektif benefit untuk masyarakat, efisien untuk mahasiswa dan profit untuk keberlanjutannya.

Selain itu ide kreatif dibutuhkan sebagai karya nyata mahasiswa di masyarakat yang membutuhkan kemampuan menyatukan smart, art serta penguasaan akar masalah dengan efektif dan efisien karena ukuran keberhasilan sebuah karya nyata diukur dari sebuah perubahan. Pemanfaatan lahan pekarangan relatif masih terbatas, sehingga pengembangan berbagai inovasi yang terkait dengan lahan pekarangan belum banyak berkembang (Winardi, 2013). Untuk mendapatkan hasil dan produktivitas yang tinggi harus dilaksanakan dengan teknik budidaya yang tepat (Latief, Tafzi dan Aryunis, 2013). Perubahan diharapkan mampu merubah kesadaran masyarakat untuk menyelesaikan masalah secara kolektif yang perlu dilakukan untuk mencari kata kunci merubah kesadaran masyarakat agar bisa meningkatkan semangat kewirausahaan dari berbagai peluang yang ada.

Pada Program PPM dan KKN Kewirausahaan ini ada pembatasan isu dikarenakan mahasiswa 
memiliki batasan dalam memberikan pengabdian dan edukasinya. Adapun isu atau topik KKN dibatasi pada lima isu yang dikembangkan berdasarkan arahan aparat desa serta karang taruna di beberapa wilayah Rukun Warga (RW) Desa Cipacing yaitu: Sakola Kerajinan Rakyat (SKR), konveksi baju, hidroponik , budidaya ikan hias dan burung, serta penanaman bibit jeruk lemon. Adapun yang menajadi program prioritas adalah penanaman bibit jeruk lemon.

\section{TINJAUAN PUSTAKA}

\section{Pemberdayaan Masyarakat}

Pemberdayaan masyarakat adalah upaya untuk memberikan daya (empowerment) atau penguatan (strengthening) kepada masyarakat. Pemberdayaan masyarakat juga diartikan sebagai kemampuan individu yang bersenyawa dengan masyarakat dalam membangun keberdayaan masyarakat yang bersangkutan sehingga bertujuan untuk menemukan alternatifalternatif baru dalam pembangunan masyarakat (Mardikanto, 2014).

\section{Kewirausahaan Berbasis Keluarga}

Wirausaha berasal dari kata wira dan usaha, wira mengandung arti manusia yang unggul sedangkan usaha mengandung arti berbuat sesuatu sehingga wirausaha yaitu seseorang yang memiliki keunggulan dalam menjalankan suatu usaha dalam hal ini mengandung pemahaman sesuatu yang bersifat bisnis. Wirausaha adalah seseorang yang mengembangkan produk baru atau ide baru dan membangun bisnis dengan konsep baru, dalam hal ini menuntut sejumlah kreativitas dan sebuah kemampuan untuk melihat trend yang berlaku untuk menjadi seorang wirausaha (Aprilianty, 2012).

Sedangkan keluarga merupakan kelompok sosial pertama-tama dalam kehidupan manusia tempat ia belajar dan menyatakan diri sebagai manusia sosial di dalam hubungan interaksi dengan kelompoknya. Interaksi sosial dalam keluarga berdasarkan simpati, seorang anak pertama-tama belajar memperhatikan keinginan-keinginan orang lain, belajar bekerja sama, bantu membantu, dengan kata lain anak pertama-tama belajar memegang peranan sebagai makhluk sosial yang mempunyai norma-norma dan kecakapan-kecakapan tertentu dalam pergaulannya dengan orang lain. Pekerjaan orang tua sering kali terlihat bahwa ada pengaruh dari orang tua yang bekerja sendiri dan membuka usaha sendiri maka cenderung anaknya akan menjadi pengusaha (Alma, 2009).

Lingkungan keluarga merupakan salah satu faktor lingkungan yang dapat mempengaruhi minat seseorang untuk berwirausaha. Soemanto (2008) mengemukakan bahwa faktor-faktor yang terkandung dalam lingkungan keluarga terdiri dari: a) Cara orang tua mendidik b) Relasi 
antar anggota keluarga.. c) Suasana rumah. d) Keadaan ekonomi keluarga e) Pengertian Orang Tua. f) Latar Belakang Kebudayaan. Tingkat pendidikan atau kebiasaan di dalam keluarga mempengaruhi sikap anak dalam kehidupannya.

Berdasarkan berbagai paparan diatas, kewirausahaan berbasis keluarga merupakan suatu kelompok sosial yang melakukan suatu usaha dengan mengembangkan produk baru ataupun ide baru didukung oleh kreativitas serta kemampuan untuk melihat trend yang berlaku di tengah-tengah masyarakat.

\section{METODE}

Metode yang digunakan adalah pendekatan secara deskriptif untuk pengambilan data agar dapat dianalisis secara kualitatif. Dalam pelaksanaan kegiatan pengabdian kepada masyarakat di Desa Cipacing ini menggunakan observasi dan wawancara, sosialisasi, serta survey dan pendataan warga pemilik lahan. Tahap pertama adalah observasi dan wawancara dilakukan untuk mengetahui lokasi dan bentuk lahan pekarangan masyarakat serta karakteristik masyarakat dalam pengelolaan lahan pekarangan. Selanjutnya tahapan kedua adalah survey dan pendataan warga pemilik lahan dilakukan untuk mengetahui warga-warga yang memiliki pekarangan lahan tanah sehingga distribusi tanaman bibit lemon bisa tepat. Tahapan ketiga adalah melakukan sosialisasi dengan menyampaikan pentingnya pemanfaatan pekarangan untuk kewirausahaan keluarga

Program ini akan dilaksanakan selama kurang lebih 30 hari dengan menyebarkan 160 bibit di wilayah yang telah disepakati oleh mahasiswa, aparat desa, karang taruna, serta warga yang menerima hibah bibit jeruk lemon. Warga yang dipilih merupakan warga yang cukup mempunyai lahan pekarangan untuk bisa ditanam dan mampu bertanggungjawab untuk terus mengelola serta merawat bibit jeruk lemon tersebut.

\section{HASIL DAN PEMBAHASAN}

Pada kegitatan KKN Tematik Kewirausahan serta PPM tahun 2020 ini terdapat empat RW yang dijadikan fokus pengembangan yaitu: RW 01, RW 07, RW 15 dan RW 18. Keempat RW tersebut masing-masing memiliki ciri khas tersendiri seperti misalnya Sakola Karajinan Rakyat (SKR) di RW 01, produsen pisau dapur dan juga konveksi di RW 07, budidaya tanaman hidroponik di RW 15 serta penangkaran burung dan budidaya ikan cupang di RW 18.

Akan tetapi, berdasarkan obervasi dan wawancara tumbuhnya potensi kewirausahaan yang 
berada di Desa Cipacing juga menimbulkan berbagai permasalahan salah satunya adalah ketidakmampuan warga lokal untuk bisa berdaya saing dengan pendatang dalam segi wirausaha itu sendiri seperti pada RW 01 yang belum mampu memaksimalkan SKR (Sakola Kerajinan Rakyat), lalu RW 07 yang yang terhambat dalam segi pemasaran serta personal branding produk pisau dapur serta konveksi, dan RW 15 dari sumber daya yang belum cukup membantu budidaya hidroponik serta RW 18 yaitu produk yang memang bersifat musiman.

Oleh karena itu disamping mahasiswa membantu kendala-kendala program yang ada di setiap RW, tim PPM mencoba untuk membuat alternatif kewirausahaan berbasis keluarga dengan penanaman bibit jeruk lemon sebagai prioritas program untuk membantu program-program lainnya.

\section{Upaya Alternatif Kewirausahaan Keluarga}

Berbagai upaya untuk kewirausahaan keluarga ini dibagi menjadi beberapa tahapan. Tahapan pertama adalah sebelum pemberian bibit jeruk lemon pada warga, dilakukan survey terlebih dahulu pada masing-masing RW yaitu RW 1, 7, 15 dan 18. Survey bertjuan untuk mengetahui warga-warga yang memiliki lahan pekarangan layak ditanami bibit jeruk lemon. Hal ini dilakukan untuk menghindari dari pemberian bibit jeruk lemon yang tidak tepat sasaran seperti dipindahkan ataupun dijual kembali. Warga-warga yang memiliki lahan pekarangan akan didata sebagai penerima bibit lemon. Setelah dilakukan survey didapat sekitar 79 Kepala Keluarga memiliki lahan pekarangan untuk siap ditanam. Jumlah bibit jeruk lemon yang disediakan sebanyak 160 lemon maka setelah dilakukan perhitungan satu rumah warga pemilik pekarangan mendapatkan masing-masing 2 bibit lemon untuk ditanam dan dirawat.

\section{Gambar 1 Proses Penyerahan Bibit Jeruk Lemon}

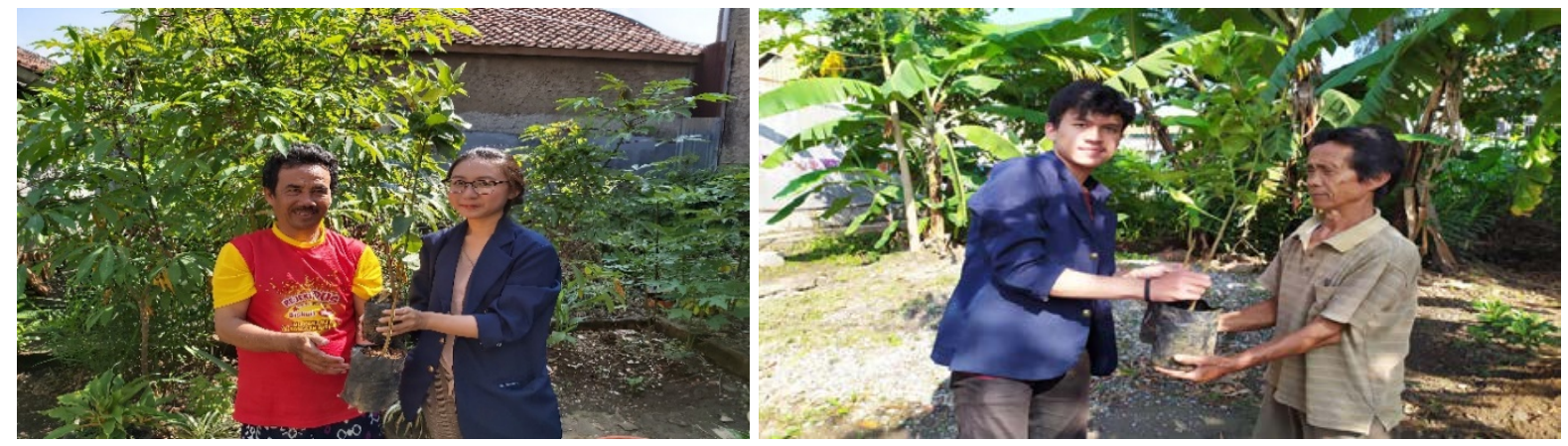

Sumber: Dokumentasi Peneliti, 2020

Tahapan kedua adalah pendistribusian bibit jeruk lemon dimana masing masing kelompok dari RW 1, 7, 15, dan 18 mendistribusikan tanaman bibit jeruk lemon dengan data survey 
sebelumnya sehingga pembagiannya sesuai kapasitas lahan pekarangan yang ada. Pendistribusian ini dilakukan sekaligus dengan penanaman yang dibantu beberapa warga seperti dari pihak karang taruna dan masing-masing ketua RW.

\section{Gambar 2 Proses Penanaman Bibit Jeruk Lemon}
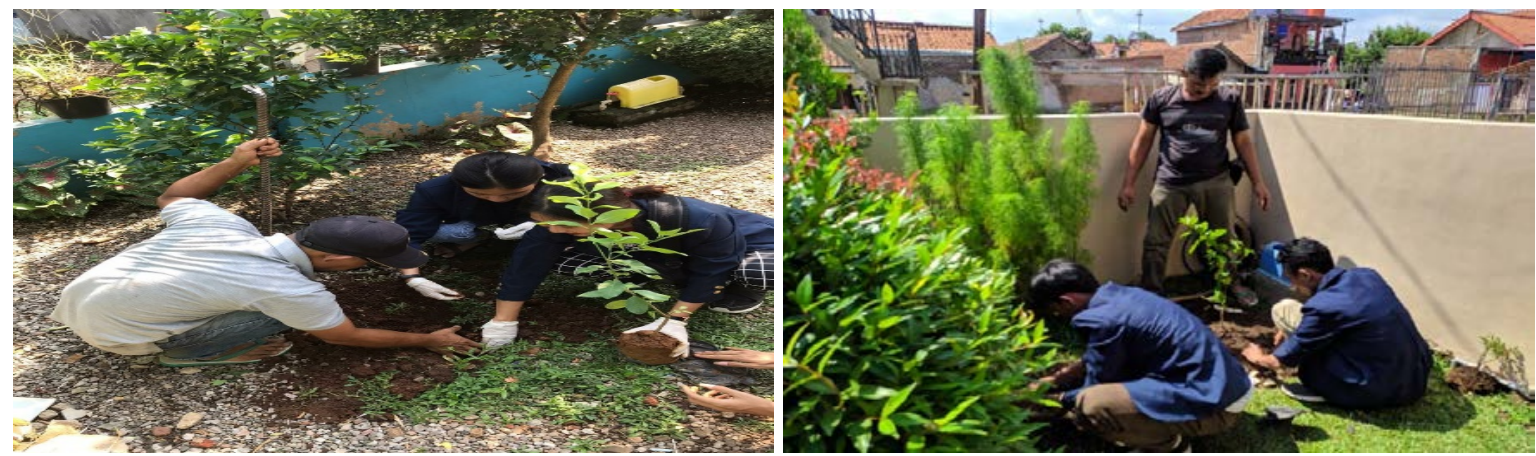

Sumber: Dokumentasi Peneliti, 2020

Setealah dilakukannya proses pendistribusian bibit jeruk lemon, selanjutnya dilakukan sosialisasi kepada para warga terkait pentingnya pemanfaatan lahan pekarangan sebagai potensi untuk berwirausaha. Pada prosesnya, setiap kelompok mahasiswa di masing-masing RW menjelaskan manfaat bibit jeruk lemon baik untuk dikonsumsi, sebagai peluang dalam berbisnis maupun sebagai sarana penghijauan di sekitar lingkungan rumah.

Tanaman jeruk lemon yang telah ditanam tersebut akan terus dipantau oleh kelompok mahasiswa selama KKN berlangsung dengan wawancara kepada setiap warga agar dapat mengetahui kondisi dan juga mengidentifikasi seberapa peduli masyarakat akan tanaman jeruk lemon tersebut.

\section{Gambar 3 Proses Pengecekan Bibit Jeruk Lemon}
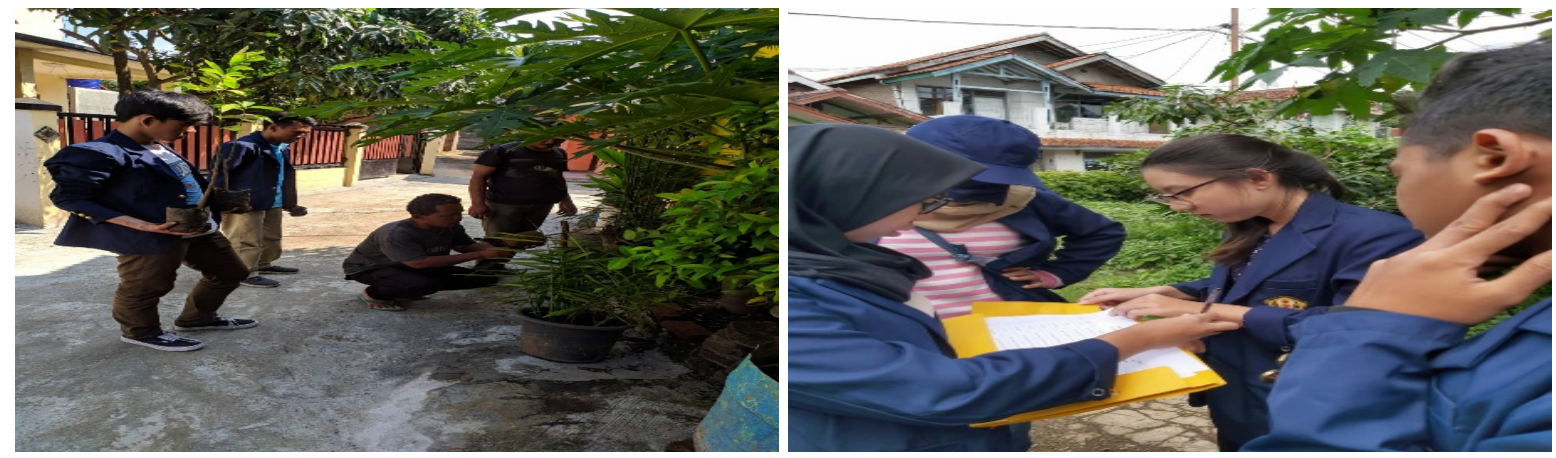

Sumber: Dokumentasi Peneliti, 2020

\section{Implementasi Program Tanam Bibit Jeruk Lemon}

Berdasarkan hasil temuan survey, angket dan wawancara serta sosialisasi kepada para warga, 
umumnya sebagian besar masyarakat mengetahui tentang nilai jual tanaman jeruk lemon yang tinggi dan bisa membantu menaikkan pendapatan keluarga, namun mereka tidak terlalu berminat untuk menjualnya dan lebih memilih untuk digunakan hasilnya sendiri. Selain itu masyarakat pada umumnya sudah mengetahui bahwa lemon merupakan buah yang memiliki banyak manfaat mulai dari obat-obatan sampai untuk kecantikan karena mengandung vitamin C serta jeruk lemon juga dapat dimanfaatkan untuk menjadi minuman.

Meskipun tanaman jeruk lemon memiliki nilai jual yang tinggi dan bisa menambah pendapatan keluarga, namun hal tersebut belum bisa mengurangi kemiskinan yang ada di desa Cipacing karena kondisi lahan di Desa Cipacing yang terbatas akibat padatnya penduduk di Desa sehingga tidak banyak masyarakat yang memiliki lahan pekarangan untuk bisa ditanami jeruk lemon. Selain itu bibit jeruk lemon belum bisa meningkatkan penghasilan keluarga karena hanya mengandalkan satu pohon dan hasil panen nya tidak akan mencukupi permintaan pasar serta membutuhkan waktu yang cukup lama dalam usia panen. Tanaman jeruk lemon memang masih belum bisa menambah pendapatan masyarakat Desa Cipacing, namun pembagian bibit jeruk lemon bisa meningkatkan kesadaran masyarakat akan penghijauan dan membuat lingkungan menjadi lebih segar khususnya di RW 15 yang berada di dekat pabrik sehingga hal ini dapat membantu usaha warga untuk menyegarkan udara di lingkungan sekitar.

Dari berbagai penjelasan diatas, dapat diketahui bahwa masyarakat Desa Cipacing khususnya di RW 01, 07, 15 dan 18 sudah mengetahui akan manfaat dari tanaman jeruk lemon tersebut. Selain itu juga masyarakat menyadari bahwa dengan adanya program penanaman tanaman jeruk lemon, masyarakat memahami bahwa penghijauan lingkungan sekitar sangatlah diperlukan mengingat wilayah Desa Cipacing merupakan pemukiman padat penduduk. Salah satu perubahan yang diharapkan dari program ini adalah mampu menumbuhkan kesadaran akan pentingnya menjaga dan merawat lingkungan, lalu semangat kewirausahaan serta pemberdayaan terhadap warga di setiap rumah yang menerima hibah bibit jeruk lemon tersebut.

Akan tetapi disisi lain masyarakat belum memahami secara jangka panjang bahwa bibit jeruk lemon tersebut bisa menghasilkan profit keberlanjutan untuk setiap keluarga. Salah satu upaya altenatif yang dapat dilakukan adalah membentuk sebuah gerakan dengan membentuk sebuah kelompok seperti GAPOKTAN (Gabungan Kelompok Tani) bibit jeruk lemon yang tersebar di 4 RW Desa Cipacing agar kedepannya bisa saling membantu dalam merawat dan mendistribusikan jeruk lemon tersebut dalam memenuhi permintaan pasar. 
Dengan demikian, perlu dilakukan kerja sama yang baik dari berbagai pihak seperti Pemerintah Desa, Lembaga Masyarakat, Masyarakat dan Kalangan Akademisi seperti Dosen dan juga Mahasiswa. Kedepannya, jika telah tercipta sinergi yang baik dari semua pihak diharapkan dapat meningkatkan tingkat kesejahteraan masyarakat secara menyeluruh dan berkelanjutan.

\section{SIMPULAN}

1. Berdasarkan hasil temuan yang telah didapatkan, umumnya masyarakat menyadari dengan adanya program tanam bibit jeruk lemon dapat meningkatkan kepedulian warga dalam upaya penghijauan di lingkungan sekitar serta mampu memberikan manfaat dari hasil merawat bibit jeruk lemon tersebut.

2. Akan tetapi secara jangka panjang masyarakat belum memahami bahwa bibit jeruk lemon yang ditanam bisa menghasilkan profit keberlanjutan untuk setiap keluarga.

3. Dengan demikian, diperlukannya pengembangan sebuah lembaga sosial seperti GAPOKTAN (Gabungan Kelompok Tani) yang dapat mengembangkan potensi warga dengan usaha bibit jeruk lemon dari mulai proses cara menanam, merawat, hingga sampai menjual.

\section{UCAPAN TERIMAKASIH}

Artikel ini disusun berdasarkan atas hasil Pengabdian Kepada Masyarakat pada KKN Tematik Kewirausahaan Tahun 2020 yang terselenggara atas kerjasama Universitas Padjadjaran dan Direktorat Jendral Pembelajaran dan Kemahasiswaan Kemenristekdikti tahun 2020. Ucapan terimakasih disampaikan kepada Rektor Universitas Padjadjaran, Dirjen Belmawa Kemenristekdikti, Dirdikmawa Universitas Padjadjaran juga pada Tim Mahasiswa KKN Tematik Kewirausahaan 2020 Desa Cipacing yaitu Bayu Fadhlurrahman, Riesda Fitriani, Adila, Indah Sari Harahap, Yanuar Pranowo, Ainna Azzahra, Moehammad Syukron Djalaluddin, Hasna Aldisa Madani, Devina Vonny Hastari, Amelia Syahna Octaviani, Muhammad Rafly Fauzan, Kelly Novelia Adjani, Fauziah Rahmah, Ghita Ramadhani Foureza, Esa Karinda Sabaruddin, Tongat Eko Prastiyo, Muhammad Fadel, Muhammad Akbar Feriansyah, Bunga Cesaria R, Firas Adinda Gandhi, Kepala Kecamatan Jatinangor, Kepala Desa dan jajarannya serta masyarakat Cipacing.

\section{DAFTAR PUSTAKA}


Alma, B. 2009. Kewirausahaan. Bandung: Alfabeta.

Ammad, F., Moumen, O., Gasem, A., Othmane, S., Hisashi, K.-N., Zebib, B., Merah, O. 2018. The Potency Of Lemon (Citrus Limon L.) Essential Oil To Control Some Fungal Diseases Of Grapevine Wood. Comptes Rendus Biologies (341): 97-101.

Aprilianty, E. (2012). Pengetahuan Kewirausahaan, Dan Lingkungan the Effect of Entrepreneur Personality, Entrepreneurship Knowledge, and Environment on Entrepreneurial Interest. Pendidikan Vokasi, 2 (3), 311-324.

Goodrich, R., 2003. CITRUS FRUITS | Lemons, in: Caballero, B. (Ed.), Encyclopedia of Food Sciences and Nutrition (Second Edition). Academic Press, Oxford, pp. 13541359.

Kurnianingsih, A. et al. 2013. Optimalisasi Lahan Pekarangan Dengan Budidaya Tanaman Lidah Buaya Yang Berkhasiat Obat Di Desa Purna Jaya Kecamatan Indralaya Utara Kabupaten Ogan Ilir. Jurnal Pengabdian Sriwijaya: 1-4.

Latief, M., Tafzi, F. dan Aryunis. 2013. Pemanfaatan Pekarangan Untuk Budidaya Tanaman Jahe Merah Untuk Meningkatkan Pendapatan Keluarga Petani Di Kelurahan Talang Barat Kecamatan Muara Sabak Barat Kabupaten Tanjung Jabang Timur. Jurnal Pengabdian Pada Masyarakat (55): 26-30.

Mardikanto, T. 2014. CSR (Corporate Social Responsibility)-(Tanggungjawab Sosial Korporasi). Bandung: Alfabeta.

Nugraha, S. 2019. Manis dan Segarnya Budi Daya Jeruk Lemon, Omzetnya Capai Rp30 Juta Per Bulan. (https://www.wartaekonomi.co.id/read235634/manis-dan-segarnya-budidaya-jeruk-lemon-omzetnya-capai-rp30-juta-per-bulan, diakses 10 Februari 2020)

Ruswadi, Rustiyadi dan Mudikdjo. 2007. Dampak Konversi Lahan Pertanian Terhadap Kesejahteraan Petani dan Perkembangan Wilayah:Study Kasus di Daerah Bandung Utara, Jurnal Argo Ekonomi 25 (2).

Soemanto, W. 2008. Pendidikan Wirausaha. Jakarta: PT. Bumi Aksara.

Winardi. 2013. Profil Pertanian Terpadu Lahan Pekarangan Di Kota Padang: Tinjauan Budidaya Pertanian. Jurnal Online Pertanian Tropik Pasca Sarjana FP USU 1(1): 21 32.

Yulida, R. 2012. Kontribusi Usahatani Lahan Pekarangan Terhadap Ekonomi Rumah Tangga 
Petani Di Kecamatan Kerinci Kabupaten Pelalawan. Indonesian Journal of Agricultural Economics (IJAE) 3(2): 135-154. 